Aspirasi: Jurnal Masalah-Masalah Sosial | Volume 11, No. 1 Juni 2020

ISSN: 2086-6305 (print) ISSN: 2614-5863 (electronic)

doi: 10.22212/aspirasi.v11i1.1294

link online: http://jurnal.dpr.go.id/index.php/aspirasi/index

\title{
Analisis Dampak Kredit Usaha Rakyat pada Sektor Usaha Mikro terhadap Penanggulangan Kemiskinan di Kota Makassar
}

\author{
Analysis of the Impact of People's Business Credit on Micro Business Sector \\ towards Poverty Alleviation in Makassar City
}

\author{
Maria Ulfa $^{1}$ dan Mohammad Mulyadi ${ }^{2}$ \\ Imuphere@gmail.com \\ Mahasiswa Pascasarjana Universitas Muslim Indonesia (UMI) Makassar \\ Jl. Urip Sumoharjo, Panakkukang, Makassar \\ ${ }^{2}$ mohammad.mulyadi@dpr.go.id \\ Pusat Penelitian Badan Keahlian DPR RI \\ Jl. Gatot Subroto, Senayan, Jakarta
}

Naskah diterima: 13 Mei 2019 | Naskah direvisi: 4 Juni 2020 | Naskah diterbitkan: 30 Juni 2020

\begin{abstract}
Community empowerment through micro-business development can be an instrument in poverty alleviation. The development of micro-businesses cannot take place by itself, therefore it needs to get financial support from the government. One form of government's support is the people's business credit (kredit usaha rakyat - KUR) which until now has been running for more than ten years. The purpose of this study was: (1) To determine the impact of the KUR on the micro-business sector; and (2) To determine the impact of the development of micro-businesses on poverty reduction. The type of research used was descriptive with a qualitative approach. The sampling technique in this study was purposive sampling with a consideration that the informants were considered the most knowledgeable about the object of this research problem (key informants). The informants consisted of officials from the Makassar City Office of Cooperatives and SMEs, business actors, and community leaders. Based on the research conducted, it is known that the KUR has a positive impact on the development of micro-businesses in Makassar City and the development of micro-businesses has a positive impact on poverty alleviation.
\end{abstract}

Keywords: micro-business; people's business credit; poverty alleviation

\begin{abstract}
Abstrak: Pemberdayaan masyarakat melalui pengembangan usaha mikro dapat menjadi sebuah instrumen dalam penanggulangan kemiskinan. Pengembangan usaha mikro tidak dapat berjalan sendiri, karenanya perlu mendapat dukungan pembiayaan dari pemerintah. Salah satu bentuk dukungan pemerintah adalah kredit usaha rakyat (KUR) yang hingga saat ini telah berjalan selama lebih dari sepuluh tahun. Tujuan dari penelitian ini adalah: (1) Untuk mengetahui dampak KUR pada sektor usaha mikro; dan (2) Untuk mengetahui dampak pengembangan usaha mikro terhadap penanggulangan kemiskinan. Jenis penelitian yang digunakan adalah deskriptif dengan pendekatan kualitatif. Teknik pengambilan sampel pada penelitian ini menggunakan purposive sampling dengan pertimbangan bahwa narasumber atau informan dianggap paling tahu tentang objek permasalahan penelitian ini (key informant). Adapun informannya terdiri dari pejabat pada Dinas Koperasi dan UKM Kota Makassar, pelaku usaha, dan tokoh masyarakat. Berdasarkan penelitian diketahui bahwa KUR memiliki dampak positif terhadap pengembangan usaha mikro di Kota Makassar dan pengembangan usaha mikro memiliki dampak positif terhadap penanggulangan kemiskinan.
\end{abstract}

Kata Kunci: kredit usaha rakyat (KUR); penanggulangan kemiskinan; usaha mikro 


\section{Pendahuluan}

Kemiskinan merupakan suatu kondisi ketika seseorang tidak dapat memenuhi kebutuhan hidupnya untuk mendapatkan kehidupan yang lebih baik atau bermartabat dari sebelumnya. Kompleksitas kemiskinan dipengaruhi oleh beberapa faktor yang saling terkait satu sama lainnya. Adapun faktor-faktor dimaksud antara lain: pendidikan, kesehatan, kondisi geografis wilayah, dan tingkat pendapatan.

Sebagai kota besar sekaligus ibukota Provinsi Sulawesi Selatan, Kota Makassar juga tidak lepas dari masalah sosial khususnya kemiskinan. Setiap tahun angka kemiskinan di Kota Makassar meningkat. Pada tahun 2015 angka kemiskinan di Kota Makassar mencapai 63.240 jiwa dari jumlah penduduk sebesar 1.449.401 jiwa, di tahun 2016 jumlah penduduk miskin 66.780 jiwa dari jumlah penduduk sebesar 1.469.601 jiwa, dan pada tahun 2017 jumlah penduduk miskin Kota Makassar sebanyak 68.190 jiwa dari jumlah penduduk sebesar 1.489.011 jiwa.

Krisis moneter yang dialami Indonesia sejak tahun 1997-1998 ditandai dengan melemahnya nilai tukar rupiah yang sangat drastis (Hamid, 2017: 120). Kejadian itu merupakan pelajaran berharga untuk mengevaluasi dan mencermati bagaimana suatu pembangunan ekonomi memiliki struktur yang kuat dan dapat bertahan dalam situasi dan kondisi apapun. Usaha mikro, kecil, dan menengah (UMKM) telah menjadi isu yang menarik untuk dicermati dan disikapi.

Data Badan Pusat Statistik dalam Profil Bisnis UMKM kerja sama LPPI dengan Bank Indonesia (2015: 1) memperlihatkan bahwa setelah krisis ekonomi tahun 1997-1998, jumlah UMKM tidak berkurang, sebaliknya justru meningkat. Sampai dengan tahun 2012, UMKM berhasil menyerap tenaga kerja sebesar 85 juta hingga 107 juta. Pada tahun itu, jumlah pengusaha di Indonesia sebanyak 56.539.560 unit. Dari jumlah tersebut jumlah UMKM sebanyak 56.534.592 unit atau 99,99\%. Sisanya, sekitar 0,01\% atau 4.968 unit adalah usaha besar. Data tersebut membuktikan bahwa UMKM mampu memberikan peluang bagi industri jasa keuangan untuk menyalurkan pinjaman kepada para pelaku UMKM, sebab masih terdapat banyak pelaku UMKM yang belum mendapatkan akses pembiayaan perbankan (LPPI \& BI, 2015: 19).

Oleh karena itu, UMKM telah menjadi isu yang menarik untuk dicermati dan disikapi karena beberapa alasan. Pertama, pada saat terjadinya krisis moneter tahun 1997 sektor UMKM dapat bertahan. Hal tersebut dikarenakan usaha mikro dan kecil (UMK) pada saat itu masih sedikit yang bersentuhan dengan nilai tukar rupiah sehingga tidak mudah terkena dampak krisis moneter yang bergejolak pada saat itu. Kedua, perhatian pemerintah pada saat itu masih kurang. Belum banyak pengusaha skala mikro dan kecil yang mengakses perbankan. Bahkan masih ada yang menggantungkan modal dari rentenir, meskipun beban bunga jauh lebih besar dari bank. Ketiga, sektor UMK sangat potensial dalam penyerapan tenaga kerja. UMKM mampu membuka kesempatan untuk mempekerjakan masyarakat yang tidak memiliki kualifikasi pendidikan dalam jumlah yang lebih besar. Keempat, sektor UMKM mampu berkontribusi terhadap perekonomian nasional, karena UMKM banyak menggunakan bahan lokal yang berkualitas ekspor dalam produksinya sehingga menggerakkan sektor riil. Berdasarkan hal tersebut, peneliti tertarik untuk meneliti dampak kredit usaha rakyat (KUR) pada sektor usaha mikro terhadap penanggulangan kemiskinan.

Kemiskinan merupakan masalah yang sering dialami oleh hampir setiap negara berkembang. Hal ini mendorong pemerintah untuk menyusun kebijakan penanggulangan kemiskinan, di antaranya kebijakan program KUR yang dipergunakan untuk membiayai usaha mikro. Berdasarkan pengamatan awal peneliti, kebijakan KUR dimaksud telah dijalankan selama kurang lebih sepuluh tahun. Akan tetapi, kemiskinan di Kota Makassar masih terlihat dengan jelas.

Berdasarkan hal tersebut, maka penelitian ini bertujuan untuk: (1) Memberi penjelasan bagaimana KUR memiliki dampak terhadap pengembangan usaha mikro dengan meneliti implementasi kebijakan KUR dari sisi: (a) Peran pemerintah dalam melakukan sosialisasi KUR dan pendampingan kepada pelaku usaha mikro; (b) Peran bank sebagai lembaga penyalur KUR dalam memberikan sosialisasi kepada masyarakat 
atau pelaku usaha mikro, termasuk kemudahan akses bagi pelaku usaha mikro yang bermohon untuk memperoleh KUR; (c) Aksesibilitas pengusaha mikro. Aksesibilitas dimaksud dalam hal ini adalah akses untuk mendapatkan informasi tentang KUR, yakni informasi yang diperoleh ketika bermohon KUR atau ketika bertanya tentang KUR, baik dari lembaga penyalur KUR maupun dari pemerintah setempat. Di samping itu, terkait dengan modal, yakni kemudahan dalam mendapatkan modal, di antaranya persyaratan yang diberikan oleh lembaga penyalur KUR ketika bermohon KUR; (2) Memberi penjelasan bagaimana pengembangan usaha mikro melalui KUR memiliki dampak terhadap penanggulangan kemiskinan dengan meneliti keberlangsungan usaha dari sisi: pengguna KUR yang merupakan pelaku usaha mikro, mencakup jumlah tenaga kerja, yakni apakah ada penambahan tenaga kerja setelah menggunakan KUR. Aset, apakah ada penambahan aset yang dimiliki setelah menggunakan KUR. Omzet, yakni jumlah uang yang didapat dari hasil penjualan dalam jangka waktu tertentu, yang belum dikurangi dengan harga pokok produksi, bahan baku, peralatan, dan lain sebagainya. Keuntungan, adalah jumlah pendapatan pelaku usaha mikro setelah dikurangi dengan omzet dan di luar dari aset. Lama usaha, yakni lama waktu yang dilalui oleh pelaku usaha mikro dalam menjalankan usahanya setelah menggunakan KUR.

Penelitian ini merupakan penelitian deskriptif dengan pendekatan kualitatif. Metode penelitian kualitatif digunakan untuk mendapatkan data yang mendalam, suatu data yang mengandung makna yang lebih rinci. Hasil penelitian ini adalah data yang diperoleh dari rekaman, pengamatan, wawancara atau bahan tertulis. Data tersebut kemudian dianalisis secara deskriptif sehingga menghasilkan gambaran mengenai dampak KUR terhadap pengembangan usaha mikro di Kota Makassar dan dampak pengembangan usaha mikro terhadap penanggulangan kemiskinan di Kota Makassar. Teknik pengambilan sampel pada penelitian ini menggunakan purposive sampling yakni pengambilan sampel secara tertentu dengan pertimbangan bahwa narasumber atau informan tersebut dianggap paling tahu tentang objek permasalahan penelitian ini. Selain itu juga digunakan snowball sampling yang merupakan teknik pengambilan sumber data, dari sedikit menjadi banyak. Hal ini disebabkan karena jumlah sumber data yang sedikit itu belum mampu memberikan data yang lengkap maka mencari narasumber lainnya untuk dapat digunakan sebagai sumber data. Pihak-pihak yang menjadi narasumber atau informan dalam penelitian ini adalah Kepala Dinas Koperasi dan UMKM Kota Makassar, Kepala Bidang Pembiayaan Simpan Pinjam Dinas Koperasi dan UKM Kota Makassar, Kepala Seksi Ekonomi Pembangunan dan Pengembangan Sistem Informasi Kantor Camat Rappocini Kota Makassar, Mantri KUR BRI Unit Rappocini, tokoh masyarakat selaku debitur, tokoh masyarakat selaku pengamat ekonomi, pelaku usaha mikro penerima KUR (penjual cendol, ayam krispi, coklat olahan, makanan rumahan, minuman), pelaku usaha mikro bukan penerima KUR (penjual bahan campuran). Hasil wawancara kemudian ditranskrip dengan kode informan sebagaimana terlihat pada Tabel 1.

Tabel 1.

Informan dan Kode Informan Penelitian

\begin{tabular}{|c|c|c|}
\hline No & Informan & $\begin{array}{c}\text { Kode } \\
\text { Infor- } \\
\text { man }\end{array}$ \\
\hline 1. & $\begin{array}{l}\text { HR. Kepala Dinas Koperasi dan UKM } \\
\text { Kota Makassar }\end{array}$ & i. 1 \\
\hline 2. & $\begin{array}{l}\text { HIK. Kepala Bidang Pembiayaan Simpan } \\
\text { Pinjam Dinas Koperasi dan UKM Kota } \\
\text { Makassar }\end{array}$ & i. 2 \\
\hline 3. & $\begin{array}{l}\text { UJ. Kepala Seksi Ekonomi Pembangunan } \\
\text { dan Pengembangan Sistem Informasi } \\
\text { Kantor Camat Rappocini Kota Makassar }\end{array}$ & i.3 \\
\hline 4. & SY. Mantri KUR BRI Unit Rappocini & i.4 \\
\hline 5. & JB. Tokoh Masyarakat/Debitur & i.5 \\
\hline 6. & $\begin{array}{l}\text { AIAM. Tokoh Masyarakat/Pengamat } \\
\text { Ekonomi }\end{array}$ & i. 6 \\
\hline 7. & $\begin{array}{l}\text { DR. Pelaku Usaha Mikro Penerima KUR/ } \\
\text { Penjual Cendol }\end{array}$ & i. 7 \\
\hline 8. & $\begin{array}{l}\text { NO. Pelaku Usaha Mikro Penerima KUR/ } \\
\text { Penjual Ayam Krispi }\end{array}$ & i.8 \\
\hline 9. & $\begin{array}{l}\text { AM. Pelaku Usaha Mikro Penerima } \\
\text { KUR/Penjual Coklat Olahan }\end{array}$ & i. 9 \\
\hline 10. & $\begin{array}{l}\text { NB. Pelaku Usaha Mikro Penerima KUR/ } \\
\text { Penjual Makanan Rumahan }\end{array}$ & i. 10 \\
\hline 11. & $\begin{array}{l}\text { ES. Pelaku Usaha Mikro Bukan Penerima } \\
\text { KUR/Penjual Minuman }\end{array}$ & i. 11 \\
\hline 12. & $\begin{array}{l}\text { DB. Pelaku Usaha Mikro Bukan } \\
\text { Penerima KUR/Penjual Bahan Campuran }\end{array}$ & i. 12 \\
\hline
\end{tabular}




\section{Kemiskinan}

Supriatna (1997) menyatakan bahwa kemiskinan adalah situasi yang serba terbatas yang terjadi bukan atas kehendak orang yang bersangkutan. Suatu penduduk dikatakan miskin bila ditandai oleh rendahnya tingkat pendidikan, produktivitas kerja, pendapatan, kesehatan, dan gizi serta kesejahteraan hidupnya, yang menunjukkan lingkaran ketidakberdayaan. Kemiskinan bisa disebabkan oleh terbatasnya sumber daya manusia yang ada, baik lewat jalur pendidikan formal maupun nonformal yang pada akhirnya menimbulkan konsekuensi terhadap rendahnya pendidikan informal.

Kemiskinan adalah sebuah fenomena multidimensional di mana hidup miskin diartikan tidak hanya hidup kekurangan dalam hal pangan, sandang, dan papan, tetapi juga berarti akses yang rendah terhadap bermacam sumber daya dan aset produktif yang dibutuhkan untuk pemenuhan kebutuhan yang paling dasar tersebut.

Secara umum masyarakat miskin tidak hanya ditandai dengan lemahnya faktor ekonomi, akan tetapi merupakan suatu ketidakberdayaan/ ketidakmampuan dalam hal: (1) memenuhi berbagai kebutuhan dasar; (2) melakukan kegiatan usaha produktif; (3) menjangkau akses sumber daya sosial dan ekonomi; (4) menentukan nasibnya sendiri dan senantiasa mendapat perlakuan diskriminatif, mempunyai perasaan ketakutan dan kecurigaan, serta sikap apatis dan fatalistik; dan (5) membebaskan diri dari mental dan budaya miskin serta senantiasa mempunyai martabat dan harga diri yang rendah (Mulyadi, 2011).

Secara lebih mendalam Sriharini (2007) mengemukakan bahwa terdapat tiga dimensi yang terkait dengan kemiskinan, yaitu:

1) Kemiskinan berdimensi ekonomi atau material. Dimensi ini menjelma dalam berbagai kebutuhan dasar manusia yang sifatnya material seperti pangan, sandang, perumahan, dan kesehatan. Dimensi ini dapat diukur dengan rupiah meskipun harganya akan selalu berubah-ubah.

2) Kemiskinan berdimensi sosial dan budaya. Ukuran kuantitatif tidak dapat dipergunakan untuk memahami dimensi ini karena ukurannya bersifat kualitatif. Lapisan yang secara ekonomis miskin akan membentuk kantong-kantong kebudayaan yang disebut budaya kemiskinan demi kelangsungan hidup mereka. Dalam teori "kemiskinan budaya" (cultural poverty) yang dikemukakan oleh Lewis (1969), disebutkan bahwa kemiskinan dapat muncul sebagai akibat adanya nilainilai atau kebudayaan yang dianut oleh orang-orang miskin, seperti malas, mudah menyerah pada nasib, dan kurang memiliki etos kerja.

3) Kemiskinan berdimensi struktural atau politik, artinya orang yang mengalami kemiskinan ekonomi pada hakikatnya karena mengalami kemiskinan struktural atau politis. Kemiskinan ini terjadi karena orang miskin tersebut tidak memiliki sarana untuk terlibat dalam proses politik dan tidak memiliki kekuatan politik sehingga menduduki struktur sosial paling bawah. Menurut pandangan ini, kemiskinan terjadi bukan dikarenakan "ketidakmauan" si miskin untuk bekerja karena malas, melainkan karena "ketidakmampuan" sistem dan struktur sosial dalam menyediakan kesempatan-kesempatan yang memungkinkan si miskin dapat bekerja.

Berdasarkan pendapat Sriharini tersebut, maka dimensi kemiskinan yang lebih dapat dilihat secara nyata dalam kehidupan sehari-hari adalah dimensi kemiskinan ekonomi atau material dan dimensi kemiskinan struktural atau politik. Hal ini karena kemiskinan ekonomi merupakan dimensi kemiskinan yang menunjukkan ketidakmampuan masyarakat dalam memenuhi kebutuhan pokoknya, seperti sandang, pangan, perumahan dan kesehatan. Sementara kemiskinan struktural atau politik menunjukkan ketidakmampuan masyarakat dalam "menembus" terbukanya jalan bagi mereka dalam meraih kehidupan yang layak.

\section{Strategi Penanggulangan Kemiskinan}

Strategi penanggulangan kemiskinan sangat dibutuhkan untuk menghadapi permasalahan kemiskinan yang kompleks. Penanggulangan kemiskinan bukan merupakan permasalahan yang dapat diatasi dalam waktu singkat, namun membutuhkan perencanaan dan sumber daya yang memadai serta melibatkan seluruh stakeholders. 
Menurut analisis data kemiskinan Kementerian Sosial Republik Indonesia dan Badan Pusat Statistik (2015), penduduk miskin memiliki karakteristik sosial dan fisik tertentu yang membuat mereka perlu mendapat perhatian agar mereka dapat keluar dari kemiskinan. Perhatian tersebut dituangkan ke dalam kebijakan untuk penanggulangan kemiskinan yang dijabarkan dalam berbagai program penanggulangan kemiskinan. Pembangunan yang dijalankan, baik dalam skala nasional maupun daerah, diarahkan agar dapat mengeluarkan kemiskinan dari penduduk atau wilayah yang miskin, sebab pembangunan juga merupakan proses perbaikan suatu perekonomian sehingga diharapkan pembangunan dapat berdampak pada pengurangan kemiskinan.

Tim Nasional Percepatan Penanggulangan Kemiskinan (TNP2K) (2011) membagi program penanggulangan kemiskinan di Indonesia ke dalam empat klaster, yakni klaster pertama merupakan program perlindungan sosial berbasis keluarga berupa bantuan siswa miskin, Jaminan Kesehatan Masyarakat, Beras Miskin (Raskin), Program Keluarga Harapan (PKH), Bantuan Langsung Tunai (BLT), dan lain-lain. Klaster kedua merupakan program-program pemberdayaan masyarakat, seperti Program Nasional Pemberdayaan Masyarakat (PNPM) Mandiri yang memiliki tujuan menciptakan kesempatan kerja, mendorong kegiatan wirausaha, pemenuhan hak kepada masyarakat untuk berpartisipasi, dan lain-lain.

Klaster ketiga merupakan program pemberdayaan UMKM, seperti KUR dan Kredit UMKM. Klaster keempat adalah program penanggulangan kemiskinan yang memuat program-program antara lain: program yang menyangkut substansi transportasi melalui program angkutan umum yang murah, substansi air bersih dengan menyediakan air bersih untuk rakyat, substansi perumahan melalui program rumah dengan harga yang murah, kelistrikan melalui program listrik yang murah dan hemat, yang semuanya bermuara untuk peningkatan taraf hidup nelayan, serta masyarakat miskin perkotaan. Penanggulangan kemiskinan tidak dapat dilakukan secara singkat dan sekaligus karena kompleksitas permasalahan yang dihadapi masyarakat miskin dan keterbatasan sumber daya untuk mewujudkan pemenuhan hak-hak dasar.

Tujuan akhir kebijakan dan strategi penanggulangan kemiskinan adalah membebaskan masyarakat dari kemiskinan dan mengangkat harkat dan martabat mereka agar menjadi warga negara dengan seluruh hak dan kewajibannya. Untuk itu salah satu strategi mendasar yang patut ditempuh adalah memberikan kesempatan seluas-luasnya bagi orang miskin untuk berpartisipasi sepenuhnya dalam proses pembangunan ekonomi. Pemerintah harus menciptakan suatu kondisi pertumbuhan ekonomi yang dapat dinikmati oleh semua lapisan masyarakat, termasuk penduduk miskin.

Oleh karena itu, pemerintah dalam mengambil kebijakan atau keputusan dalam lingkup pembangunan ekonomi, maka seharusnya dititikberatkan pada sektor ekonomi riil yang akan berpengaruh pada kehidupan masyarakat miskin baik secara langsung maupun tidak langsung, seperti berpengaruh pada kehidupan masyarakat miskin pertanian, perikanan, usaha kecil dan menengah, serta sektor informal.

Upaya untuk memperkuat ketahanan ekonomi masyarakat tidak mudah. Ada sejumlah hambatan yang biasanya jadi ganjalan untuk membangun kemampuan ekonomi masyarakat. Tetapi, apapun hambatannya, penguatan ekonomi masyarakat tetap harus dilakukan.

\section{Kredit Usaha Rakyat}

KUR merupakan salah satu program kebijakan yang diambil pemerintah pada tahun 2007 yang bertujuan dalam penanggulangan kemiskinan dengan berbasis pada pemberdayaan usaha ekonomi mikro, kecil, dan menengah. Salah satu manfaat dari KUR yang selama ini dirasakan oleh pelaku UMKM adalah kemudahan dalam mengakses bank. KUR secara teknis memberikan akses kepada pelaku UMKM terhadap perbankan.

Menurut Putra (2013), KUR adalah suatu upaya pemerintah dalam penanggulangan kemiskinan dengan mendorong perbankan menyalurkan kredit kepada UMKM. Penyaluran KUR sebagaimana diatur oleh pemerintah melalui Peraturan Menteri Keuangan No. 135/ PMK.05/2008 tentang Fasilitas Penjaminan Kredit Usaha Rakyat yang telah diubah 
dengan Peraturan Menteri Keuangan No. 10/ PMK.05/2009 di mana di dalamnya terdapat beberapa ketentuan yang dipersyaratkan oleh pemerintah, yakni usaha mikro yang dapat menerima fasilitas penjaminan merupakan usaha produktif yang memiliki kelayakan (feasible) untuk mendapatkan fasilitas kredit dari bank.

Bantuan diberikan meskipun usaha mikro tersebut belum bersifat bankable atau dalam arti pelaku UMKM tersebut belum pernah mendapatkan pembiayaan dari bank lainnya. Hal ini dapat diketahui melalui Sistem Informasi Debitur (SID) yaitu ketika permohonan kredit diajukan atau belum pernah mendapat fasilitas kredit program dari pemerintah secara khusus. KUR akan diberikan dengan perjanjian antara debitur dengan lembaga penyalur KUR.

\section{Usaha Mikro}

UU UMKM menyebutkan definisi usaha mikro sebagai sebuah usaha produktif yang merupakan milik orang perorangan dan/atau badan usaha perorangan yang memenuhi kriteria usaha mikro sebagaimana diatur dalam UU UMKM.

Secara rinci, menurut Keputusan Menteri Keuangan No. 40/KMK.06/2003 tentang Pendanaan Kredit Usaha Mikro dan Kecil, usaha mikro dapat diartikan sebagai usaha yang bersifat produktif yang baik merupakan milik keluarga maupun perorangan warga negara Indonesia (WNI), yang memiliki penjualan dengan hasil maksimal Rp100.000.000 (seratus juta rupiah) per tahun. Setiap pelaku usaha mikro dapat mengajukan kredit kepada bank paling banyak Rp50.000.000.

Terdapat beberapa ciri usaha mikro yakni: (1) Jenis barang/komoditi usahanya tidak selalu tetap, sewaktu-waktu dapat berganti, para pelaku usaha mikro terkadang menjual produk berdasarkan produk yang cenderung dinikmati oleh konsumen. (2) Pelaku usaha mikro memiliki tempat usaha yang tidak selalu menetap, sewaktu-waktu dapat berpindah tempat. (3) Pemilik usaha belum memiliki administrasi keuangan, bahkan administrasi yang sederhana sekalipun, terkadang masih menggabungkan keuangan keluarga dengan keuangan usaha. (4) Pemilik usaha atau sumber daya manusia pelaku usaha masih memiliki strata pendidikan yang rendah. (5) Pada umumnya, pelaku usaha mikro tidak memiliki izin usaha atau persyaratan legalitas lainnya termasuk Nomor Pokok Wajib Pajak (NPWP). (6) Umumnya tenaga kerja atau karyawan yang dimiliki kurang dari empat orang, bahkan karyawan yang dipekerjakan masih memiliki hubungan keluarga.

\section{Kebijakan Kredit Usaha Rakyat dalam Pengembangan Usaha Mikro}

Program KUR dianggap mampu memberikan dampak positif terhadap pemberdayaan UMKM sehingga dapat dijadikan kendaraan untuk meningkatkan kesempatan kerja, pendapatan pelaku usaha UMKM, dan menurunkan tingkat kemiskinan (Iztihar, 2018). Salah satu upaya yang tengah dilakukan oleh pemerintah adalah dengan menggerakkan sektor UMKM melalui akses perkreditan pada lembaga keuangan. Dengan langkah tersebut, maka sektor UMKM akan lebih berdaya yang pada akhirnya akan berakibat pada pengurangan jumlah angka kemiskinan (Dharma, Sumartono, \& Sarwono, 2016: 44).

Nugroho (2016) menyebutkan bahwa kelompok miskin kesulitan untuk mengakses skim kredit mikro dari program PNPM Mandiri karena desain program yang cenderung membatasi kelompok miskin tersebut. Selama ini masih terdapat pihak perbankan yang masih ragu dalam memberikan pinjaman kepada pelaku usaha mikro sehingga sulit untuk mendapatkan modal awal dan/atau tambahan modal. Seharusnya dengan adanya penjaminan kredit, perbankan tidak ragu lagi dalam memberikan kredit pada sektor usaha mikro. Hasil akhir dari usaha mikro yang memperoleh modal kerja atau investasi perbankan sangat beragam. Mulai dari menggerakkan sektor riil, menyerap tenaga kerja, serta memberikan stimulus bagi perekonomian sehingga masyarakat lebih mandiri dalam meningkatkan kesejahteraan mereka

Padahal, salah satu bentuk penguatan ekonomi masyarakat adalah dengan pemberdayaan masyarakat ekonomi lemah yang berasal dari usaha mikro. Kekuatan ekonomi lemah yang melekat pada usaha mikro dapat diperkuat pemerintah dengan jalan memberikan kemudahan dalam memperoleh akses modal 
dari perbankan melalui mekanisme penjaminan kredit. Adanya intermediasi perbankan akan mempermudah akses permodalan bagi pihak kekurangan dana. Masyarakat yang kekurangan dana dapat memperoleh akses modal dalam bentuk kredit atau bentuk-bentuk lainnya dalam rangka meningkatkan taraf hidupnya (Saunders \& Cornett, 2008).

Setiap kebijakan yang diambil atau disusun oleh pemerintah, telah dilakukan telaah atas hal tersebut dengan mempertimbangkan asas manfaat dan tujuan. Begitu pula dengan KUR yang diluncurkan pada tanggal 5 November 2007. Salah satu tujuan adanya KUR ini adalah untuk membiayai usaha mikro yang bersifat feasible. Feasible yang dimaksud adalah usaha mikro yang memiliki kelayakan potensi, prospek bisnis yang baik, dan mempunyai kemampuan untuk mengembalikan pinjaman.

UMKM merupakan usaha yang potensial dan memiliki peran penting dalam mendorong pertumbuhan ekonomi, menciptakan kesempatan kerja, dan memperkuat struktur ekspor. UMKM juga memiliki peran penting dalam percepatan penanggulangan kemiskinan. UMKM menghasilkan produk yang kemudian dikonsumsi oleh kelompok masyarakat menengah bawah (Widyaresti \& Setiawan, 2012).

Beberapa bank di beberapa kabupaten dan kota baik bank BUMN maupun swasta menjadi penyalur KUR, begitu pula di Kota Makassar. Beberapa bank BUMN menyalurkan bantuan KUR kepada pengusaha-pengusaha mikro di kota Makassar. Diharapkan agar KUR membantu pelaku usaha mikro mengembangkan usaha yang digelutinya. KUR yang diperoleh dapat dipergunakan mulai dari sisi produksi hingga pemasarannya.

\section{Dampak Kebijakan Kredit Usaha Rakyat terhadap Pengembangan Usaha Mikro di Kota Makassar}

\section{Peran Pemerintah Daerah}

Sejak Undang-Undang tentang Pemerintah Daerah berlaku, kekuasaan tidak lagi hanya berpusat pada pemerintah pusat. Mulai ada pembagian beberapa kewenangan dari pusat kepada daerah guna menjalankan urusan pemerintah secara mandiri menurut asas otonomi dan tugas pembantuan. Pemberian kekuasaan kepada pemerintah daerah bertujuan untuk mempercepat terwujudnya kesejahteraan bagi masyarakat di daerah tersebut. Salah satu faktor yang perlu diperhatikan oleh pemerintah daerah adalah sektor ekonomi khususnya pengembangan usaha mikro.

Pengembangan usaha mikro melalui pemberdayaan menjadi salah satu tugas pemerintah daerah. Tugas tersebut bertujuan untuk mengangkat serta memberikan dukungan ekonomi kepada masyarakat secara nyata. Dukungan pemerintah daerah dimaksudkan agar masyarakat memiliki kemampuan untuk mengembangkan potensi yang ada, terutama mengembangkan usaha berskala kecil. Tujuan dari pengembangan usaha mikro adalah terciptanya lapangan pekerjaan untuk masyarakat, serta mengembangkan kemandirian masyarakat dalam memenuhi kebutuhan ekonominya

Dari wawancara, diketahui bahwa Pemerintah Kota Makassar melalui Dinas Koperasi dan UKM memiliki peran penting terhadap pengembangan usaha mikro, antara lain dengan melakukan sosialisasi untuk menyampaikan informasi tentang adanya KUR.

Kegiatan sosialisasi oleh Dinas Koperasi dan UKM dilaksanakan dengan mengundang para pelaku usaha mikro, dan dari pihak bank untuk memberikan gambaran pinjaman KUR. Berdasarkan hasil wawancara dengan informan penelitian, diketahui bahwa sosialisasi dan penyuluhan dilakukan dengan cara bertahap dan digilir. Penggiliran dilakukan berdasarkan database pelaku UMK yang ada. Database telah diverifikasi by name dan by address, dengan tujuan memberikan permodalan untuk mendorong/support usaha agar bisa maju dan berkembang (HR, W, 2/4/2019).

Dinas Koperasi dan UKM Kota Makassar memfasilitasi pelaku usaha yang usahanya sudah berjalan enam bulan untuk bertemu dengan bank penyalur KUR agar mereka dapat mengetahui bentuk-bentuk pinjaman dan mengajukannya dengan mudah kepada pihak bank (HIK, W, 4/4/2019).

Selain sosialisasi dan memfasilitasi pertemuan antara pelaku usaha dan pihak bank, Dinas Koperasi dan UKM Kota Makassar juga 
melakukan pendampingan. Pendampingan diberikan dalam bentuk pelatihan kepada pelaku usaha mikro untuk meningkatkan kualitas produk dan juga kemasan. Kegiatan tersebut dilakukan dengan mengumpulkan 30 (tiga puluh) pelaku usaha mikro untuk dilatih dan diberikan pembinaan tentang cara mengembangkan usaha melalui peningkatan kualitas produk usaha yang mereka miliki dan jaminan pemasarannya. Jangan sampai produk yang sudah dihasilkan gagal dipasarkan dan menjadi rusak (UJ, W, 5/4/2019).

\section{Peran Lembaga Penyalur Kredit Usaha Rakyat}

Perkembangan lembaga penyalur KUR terjadi seiring dengan perkembangan UKM serta masih banyaknya hambatan UKM dalam mengakses sumber-sumber pembiayaan dari lembaga-lembaga keuangan formal. Selain itu, berkembangnya lembaga pembiayaan ini juga tidak terlepas dari karakteristiknya yang memberikan kemudahan kepada pelaku UKM dalam mengakses sumber-sumber pembiayaan.

Peran lembaga penyalur KUR dalam memberikan pinjaman kepada para pelaku UKM dipandang positif. Manfaat kredit pinjaman dapat digunakan untuk meningkatkan modal usaha dan produksi. KUR diharapkan mampu menaikkan pendapatan atau kesejahteraan masyarakat.

Peran lembaga penyalur KUR dalam hal ini pihak bank penyalur tersebut tampak ketika Pemerintah Kota Makassar meminta untuk memberikan gambaran atau sosialisasi tentang KUR di hadapan para pelaku usaha. Hasil dari sosialisasi tersebut, mendorong pelaku usaha mikro mengajukan pinjaman dan melalui aplikasi BRISpot. Pelaku usaha dapat dengan mudah mengajukan pinjaman KUR dan terealisasi maksimal dua hari. Lebih lanjut dalam wawancara dengan informan, diketahui persyaratan yang dilampirkan oleh pelaku usaha mikro cukup melengkapi dokumen antara lain: Kartu Tanda Penduduk (KTP), Kartu Keluarga (KK), Buku Nikah, dan Surat Keterangan Usaha (SY, W, 5/4/19).

Mengacu pada hasil wawancara di atas, maka diketahui bahwa bank penyalur KUR memiliki peran dalam melakukan sosialisasi terhadap pelaku usaha mikro, serta memberikan kemudahan dalam memperoleh KUR setelah berkas dilengkapi. Walaupun biaya atas dana pinjaman dari lembaga pembiayaan lebih tinggi sedikit dari tingkat bunga perbankan, lembaga pembiayaan memberikan kelebihan misalnya berupa tidak adanya jaminan/agunan seperti yang dipersyaratkan oleh perbankan. Bahkan dalam beberapa jenis lembaga, pinjaman didasarkan pada kepercayaan karena biasanya peminjam beserta aktivitasnya sudah dikenal oleh lembaga keuangan mikro. Kemudahan yang lain adalah pencairan dan pengembalian pinjaman yang fleksibel disesuaikan dengan cash flow peminjam.

\section{Aksesibilitas Pelaku Usaha Mikro dalam Mendapatkan Informasi Kredit Usaha Rakyat dan Modal Usaha}

Masalah informasi KUR dan permodalan merupakan masalah yang pada umumnya dirasakan oleh pelaku usaha khususnya UMK. Keterbatasan modal yang masih rendah dari UMK disebabkan karena rendahnya aksesibilitas pelaku usaha pada lembaga-lembaga kredit formal perbankan sehingga cenderung menggantungkan pembiayaan usahanya dari modal sendiri atau sumber-sumber lain seperti keluarga, kerabat, atau bahkan rentenir.

Aksesibilitas pelaku usaha mikro mendapat KUR dapat dilihat dalam mendapatkan informasi KUR terkait modal usaha. Salah satu bank yang mempunyai perhatian serius terhadap upaya Pemerintah Kota Makassar khususnya Dinas Koperasi dan UKM dalam pengembangan usaha mikro adalah Bank BRI. Berdasarkan hasil wawancara dengan informan yang berprofesi sebagai penjual es cendol, diketahui bahwa: "Selama ini saya mengambil pinjaman KUR di BRI lancar dan tidak sulit. Informasi yang disampaikan tentang mekanisme pinjaman sangat mudah dipahami. Selama persyaratan yang diajukan lengkap, maka pihak bank akan merealisasikan segera pinjaman yang kita ajukan" (DR, W, 5/4/19).

Hasil wawancara tersebut di atas, menunjukkan bahwa aksesibilitas pelaku usaha mikro cukup baik dalam mendapatkan informasi yang dibutuhkan ketika akan mengajukan permohonan modal usaha. Selama ini persyaratan yang dilampirkan untuk diajukan dalam berkas pengajuan pinjaman tidak begitu sulit sehingga 
mudah bagi pelaku usaha. Faktor aksesibilitas pelaku usaha mikro dalam menjangkau informasi dalam pelaksanaan KUR menjadi penting sebab informasi yang didapatkan oleh pelaku usaha akan lebih memudahkan mereka dalam memenuhi persyaratan yang harus diajukan untuk menambah modal usaha.

\section{Dampak Pengembangan Usaha Mikro terhadap Penanggulangan Kemiskinan di Kota Makassar}

Keberadaan usaha mikro sangat penting dalam upaya mengurangi kemiskinan di Indonesia. Sejak otonomi daerah diberlakukan khususnya desentralisasi fiskal, upaya pemerintah daerah untuk mengurangi jumlah orang miskin di daerah terus dilakukan. Salah satu caranya adalah dengan mengembangkan usaha mikro di daerah yang menjadi motor penggerak pertumbuhan ekonomi daerah.

Secara umum dampak pengembangan usaha mikro dapat dilihat pada adanya perubahan taraf hidup pelaku usaha yang semakin meningkat. Hal ini tercermin melalui adanya penambahan jumlah tenaga kerja, penambahan omzet yang dimiliki oleh pelaku usaha, bertambahnya keuntungan, dan lain sebagainya. Salah satu informan yang berprofesi sebagai penjual ayam krispi menyebutkan bahwa: "Setelah mengambil KUR, usaha saya lebih berkembang. Saya sudah bisa mencicil kendaraan bermotor dan membiayai kuliah anak-anak. Selain itu omzet saya mencapai lebih dari Rp1.000.000 per hari. Saya merasa telah ada perbaikan ekonomi" (NO, W, 5/4/19). Hal yang sama juga disampaikan oleh pelaku usaha mikro, yang berprofesi sebagai penjual makanan rumahan, di mana dulu sebelum ada pinjaman KUR, sulit baginya untuk menambah modal. Tapi setelah ada, usahanya semakin maju dan ia sudah bisa menabung (NB, W, 3/4/19).

Adanya perbaikan taraf kehidupan yang ditandai dengan berkembangnya usaha yang dijalankan sangat dirasakan oleh berbagai kalangan, termasuk anak-anak muda yang juga merasakan manfaatnya. Hal ini dijelaskan oleh salah salah satu informan, bahwa usaha yang dijalankannya baru berjalan empat bulan, dengan modal Rp4.000.000. Saat ini ia sudah bisa mencicil kendaraan bermotor dan juga tidak bergantung lagi dengan orang tua (ES, W, 5/4/19).

Perbaikan taraf hidup juga dirasakan oleh salah satu pelaku usaha mikro yang menjelaskan bahwa: "Bermodal Rp25.000, pada tahun 2008 saya memulai usaha mikro. Sebelumnya tidak dapat pinjaman dikarenakan usahanya masih baru. Setelah lima tahun berjalan barulah mendapat pinjaman KUR dan sekarang ini usaha saya sudah mempekerjakan sepuluh karyawan. Varian produknya lebih banyak serta sudah dikirim ke luar provinsi Sulawesi Selatan juga. Menurut saya, pengembangan usaha mikro sangat efektif terhadap penanggulangan kemiskinan" (AM, W, 6/4/19).

Adapun menurut Kepala Bidang Pembiayaan Simpan Pinjam Dinas Koperasi dan UKM Kota Makassar, terkait bagaimana hubungan usaha mikro dalam efektivitas penanggulangan kemiskinan, dijelaskan bahwa: "Penanggulangan kemiskinan dapat dilakukan melalui pengembangan usaha mikro, sebab melalui pinjaman yang diberikan oleh bank, usaha mikro menjadi berkembang dan menambah penghasilan kemudian memperbaiki taraf hidup pelaku usaha tersebut" (HIK, W, 4/4/19).

Hal tersebut sejalan dengan apa yang disampaikan oleh Mantri KUR PT. BRI (Persero) Unit Rappocini, bahwa KUR mampu mendorong pengembangan usaha mikro dan efektif dalam penanggulangan kemiskinan. Penjelasan lebih lanjut disampaikan dengan memberikan contoh bahwa salah satu nasabah KUR yang dibina sejak tahun 2013 sampai dengan 2019 karena keuletannya dalam usaha kelontong, sekarang sudah memiliki rumah dan membeli kendaraan roda empat secara cash (SY, W, 5/4/19).

Menurut salah satu tokoh masyarakat yang aktif juga sebagai debitur pada salah satu Bank BUMN, bahwa:

"Usaha mikro memiliki dampak terhadap penanggulangan kemiskinan, sebab secara umum kebijakan pemerintah terkait penyediaan KUR untuk usaha mikro merupakan angin segar bagi para pelaku usaha mikro. Hal tersebut disebabkan adanya faktor dukungan permodalan yang selama ini menjadi kendala utama, sudah dapat tertangani. Namun demikian, masih ada permasalahan lain yang sangat strategis yang perlu diparalelkan, yakni kualitas para pelaku 
usaha mikro. Selain itu, pengaruh pada aspek lain, dari kebijakan KUR ini akan memperkokoh struktur perekonomian masyarakat, khususnya di Indonesia. Kita ketahui bahwa gejolak ekonomi dunia banyak berimplikasi kepada negara-negara berkembang, akan tetapi untuk Indonesia, pertumbuhan ekonomi melambat dari yang direncanakan oleh pemerintah. Adapun terkait dengan kemiskinan tentunya tidak terlepas dari data. Kebijakan KUR ini secara umum menggeliatkan ekonomi masyarakat secara otomatis akan membuka lapangan kerja dan menekan angka pengangguran. Persoalan kemiskinan di Indonesia, bukan persoalan sektoral yang hanya dapat dilihat dari sisi ekonomi saja akan tetapi berbagai sektor yang memengaruhi. Kebijakan KUR ini hanya salah satu bagian dari upaya pemerintah dalam rangka pengendalian jumlah penduduk miskin. Pada prinsipnya pengembangan usaha terhadap penanggulangan kemiskinan akan efektif karena usaha ini bersentuhan langsung dengan masyarakat menengah ke bawah. Akan tetapi yang terpenting adalah identifikasi potensi pasar, karena kegagalan pengembangan usaha mikro sebagian besar karena ketidaksesuaian dengan permintaan pasar" (JB, W, 7/4/19).

Hal tersebut senada dengan tokoh masyarakat lainnya yang juga pengamat ekonomi, bahwa:

"Pengembangan usaha mikro merupakan salah satu sarana dalam penanggulangan kemiskinan. Hal ini tampak pada pemberdayaan melalui pengembangan usaha mikro merupakan salah satu cara untuk menanggulangi kemiskinan yang ada dalam suatu kota, termasuk Makassar. Kalangan keluarga miskin dapat diberikan akses agar dapat mengembangkan usaha yang produktif. Perlu diketahui dan diingat bahwa dampak dari pembangunan perekonomian suatu negara adalah berkurangnya jumlah penduduk miskin dan tujuan pembangunan tersebut berkaitan erat dengan upaya mengurangi kemiskinan dan kesenjangan pendapatan. Pengembangan sektor usaha mikro dapat menjadi salah satu upaya yang dilakukan oleh pemerintah dalam mengatasi kemiskinan" (AIAM, 7/4/19).

Berdasarkan berbagai temuan yang telah diuraikan oleh beberapa informan penelitian, KUR memiliki dampak positif terhadap pengembangan usaha mikro di Kota Makassar. Hal ini dapat dilihat pada tujuan implementasi program KUR di Kota Makassar yaitu mendorong berkembangnya usaha mikro, di mana untuk mendukung pengembangan usaha mikro tersebut, terdapat dua unsur yang memiliki peranan penting yakni: (1) Peran pemerintah daerah dalam mendorong atau mendukung pelaku usaha mikro dengan memfasilitasi para pelaku usaha mikro dengan perbankan atau lembaga penyalur KUR dalam bentuk sosialisasi dan pendampingan dengan memberikan pendidikan, penyuluhan, dan pelatihan; (2) Peran lembaga penyalur KUR (perbankan) dalam memberikan aksesibilitas bagi pelaku usaha mikro yang mengajukan pinjaman.

Selain itu, pengembangan usaha mikro memilikidampakpositifterhadappenanggulangan kemiskinan, karena pengembangan usaha mikro bertujuan untuk mengembangkan, memandirikan, dan memberdayakan para pelaku usaha mikro sehingga pelaku usaha mikro dapat meningkatkan taraf hidupnya.

\section{Penutup}

Pemerintah termasuk lembaga penyalur telah melakukan sosialisasi terkait program kredit usaha rakyat (KUR). Hal tersebut dapat dilihat dari berbagai kegiatan sosialisasi yang dilakukan oleh berbagai dinas terkait dan lembaga penyalur seperti bank yang menerangkan tentang manfaat KUR tersebut untuk mendapatkan dana modal usaha. Oleh karena itu, perlu sosialisasi secara terus-menerus oleh pemerintah daerah bersama lembaga penyalur kepada masyarakat yang akan mulai membangun usaha agar dapat mengajukan KUR sebagai dana awal modal usaha. Hal ini akan menghindarkan para pelaku usaha mikro dari rentenir yang menawarkan pinjaman dengan bunga yang tinggi.

Sosialisasi program KUR tersebut diharapkan membantu masyarakat dalam mengembangkan perekonomian usahanya. Program ini sebaiknya tetap dipertahankan dan lebih ditingkatkan agar dapat berjalan semakin baik dan optimal dalam pencapaian tujuan program KUR. Hal tersebut dapat terlaksana jika Pemerintah Kota Makassar senantiasa melakukan koordinasi dengan lembaga penyalur KUR untuk memantau perkembangan usaha mikro dengan meningkatkan kapasitas produksinya yang tentunya memerlukan modal yang tidak sedikit. Minimnya permodalan dan rendahnya kemampuan serta pengetahuan pengelola usaha menengah dan kecil (UMK) 
membuat UMK belum mampu bersaing sehingga terkadang membuat mayoritas UMK beroperasi dalam waktu yang relatif tidak lama. Oleh karena itu, peningkatan akses pembiayaan dan perluasan skema pembiayaan bagi UMK adalah salah satu arah pembangunan untuk meningkatkan daya saing usaha.

Pemerintah Kota Makassar perlu memperkuat pemberdayaan masyarakat miskin dengan memberikan sosialisasi tentang perbaikan taraf hidup melalui usaha mikro dan edukasi tentang produk yang berkualitas dan strategi pasar sehingga pelaku usaha mikro dapat menjalankan usahanya secara berkelanjutan atau terusmenerus. Taraf hidup masyarakat diharapkan dapat menjadi lebih sejahtera dan lepas dari kemiskinan.

Di samping Pemerintah Kota Makassar, bank penyalur KUR juga harus memberikan edukasi tentang keberadaan KUR sehingga masyarakat atau calon debitur paham tentang manfaat KUR dalam pengembangan usaha mikro. Edukasi bagi masyarakat yang juga diberikan adalah mengenai cara mengelola keuangan sehingga pelaku usaha pengguna KUR juga memiliki kewajiban untuk mengelola usahanya dengan baik.

\section{Daftar Pustaka}

AIAM. (2019). Analisis Dampak Kredit Usaha Rakyat pada Sektor Usaha Mikro terhadap Penanggulangan Kemiskinan di Kota Makassarl Pewawancara: Maria Ulfa, Universitas Muslim Indonesia (UMI), Makassar.

AM. (2019). Analisis Dampak Kredit Usaha Rakyat pada Sektor Usaha Mikro terhadap Penanggulangan Kemiskinan di Kota Makassarl Pewawancara: Maria Ulfa, Universitas Muslim Indonesia (UMI), Makassar.

Badan Pusat Statistik. (2015). Penghitungan dan Analisis Kemiskinan Makro Indonesia Tahun 2015. Jakarta: Badan Pusat Statistik.

DB. (2019). Analisis Dampak Kredit Usaha Rakyat pada Sektor Usaha Mikro terhadap Penanggulangan Kemiskinan di Kota Makassarl Pewawancara: Maria Ulfa, Universitas Muslim Indonesia (UMI), Makassar.
Dharma, B. A., Sumartono, S., \& Sarwono. (2016). Implementasi Kebijakan Penanggulangan Kemiskinan Melalui Kurmikro PT. BRI Unit Soekarno-Hatta. Jurnal Ilmiah Ilmu Administrasi Publik, 6(1), 43-50.

DR. (2019). Analisis Dampak Kredit Usaha Rakyat pada Sektor Usaha Mikro terhadap Penanggulangan Kemiskinan di Kota Makassarl Pewawancara: Maria Ulfa, Universitas Muslim Indonesia (UMI), Makassar.

ES. (2019). Analisis Dampak Kredit Usaha Rakyat pada Sektor Usaha Mikro terhadap Penanggulangan Kemiskinan di Kota Makassarl Pewawancara: Maria Ulfa, Universitas Muslim Indonesia (UMI), Makassar.

Hamid, E. S. (2017). Perekonomian Indonesia. Jakarta: Universitas Terbuka.

HIK. (2019). Analisis Dampak Kredit Usaha Rakyat pada Sektor Usaha Mikro terhadap Penanggulangan Kemiskinan di Kota Makassar/ Pewawancara: Maria Ulfa, Universitas Muslim Indonesia (UMI), Makassar.

HR. (2019). Analisis Dampak Kredit Usaha Rakyat pada Sektor Usaha Mikro terhadap Penanggulangan Kemiskinan di Kota Makassar/ Pewawancara: Maria Ulfa, Universitas Muslim Indonesia (UMI), Makassar.

Iztihar, I. (2018). Analisis Pengaruh Kredit Usaha Rakyat Terhadap Penanggulangan Kemiskinan, Pengembangan Usaha Kecil Dan Perekonomian Di Indonesia. Jurnal Ilmiah Mahasiswa FEB, $6(2)$.

JB. (2019). Analisis Dampak Kredit Usaha Rakyat pada Sektor Usaha Mikro terhadap Penanggulangan Kemiskinan di Kota Makassarl Pewawancara: Maria Ulfa, Universitas Muslim Indonesia (UMI), Makassar.

Lembaga Pengembangan Perbankan Indonesia (LPPI) \& Bank Indonesia (BI). (2015). Profil Bisnis Usaha Mikro, Kecil dan Menengah. Jakarta: Lembaga Pengembangan Perbankan Indonesia (LPPI) \& Bank Indonesia (BI).

Mulyadi, M. (2011). Kemiskinan Identifikasi Penyebab dan Penanggulangannya. Jakarta: Nadi Pustaka.

NB. (2019). Analisis Dampak Kredit Usaha Rakyat pada Sektor Usaha Mikro terhadap Penanggulangan Kemiskinan di Kota Makassarl Pewawancara: Maria Ulfa, Universitas Muslim Indonesia (UMI), Makassar. 
NO. (2019). Analisis Dampak Kredit Usaha Rakyat pada Sektor Usaha Mikro terhadap Penanggulangan Kemiskinan di Kota Makassar/ Pewawancara: Maria Ulfa, Universitas Muslim Indonesia (UMI), Makassar.

Nugroho, A. E. (2016). Komersialisasi Kredit Program Untuk Pengembangan UMKM dan Penanggulangan Kemiskinan: Kasus Kredit Usaha Rakyat. Jakarta: LIPI Press.

Putra, S. I. G. (2013). Efektivitas dan Dampak Program Bantuan Kredit Usaha Rakyat (KUR) Terhadap Pendapatan dan Kesempatan Kerja Usaha Mikro, Kecil, dan Menengah (UMKM) di Kota Denpasar. Skripsi. Universitas Udayana: Denpasar.

Saunders, A. \& Cornett, M. M. (2008). Financial Institutions Management: A Risk Management Approach (Sixth Edition). New York: Mc GrawHill International Edition.

Sriharini. (2007). Strategi Pemberdayaan Masyarakat Miskin, in Misbahul Ulum dkk., Model-model Kesejahteraan Sosial Islam. Perspektif Normatif Filosofis dan Praktis. Yogyakarta: PT. LkiS Pelangi Aksara.

Supriatna, T. (1997). Birokrasi, Pemberdayaan, dan Pengentasan Kemiskinan. Bandung: Humaniora Utama Press.

SY. (2019). Analisis Dampak Kredit Usaha Rakyat pada Sektor Usaha Mikro terhadap Penanggulangan Kemiskinan di Kota Makassar/ Pewawancara: Maria Ulfa, Universitas Muslim Indonesia (UMI), Makassar.

Tim Nasional Percepatan Penanggulangan Kemiskinan (TNP2K). (2011). Percepatan Penanggulangan Kemiskinan. Retrieved from http://www.tnp2k.go.id/images/uploads/ downloads/Percepatan $\% 20$ Penanggulangan $\% 20$ Kemiskinan.pdf, on May 30, 2020.

UJ. (2019). Analisis Dampak Kredit Usaha Rakyat pada Sektor Usaha Mikro terhadap Penanggulangan Kemiskinan di Kota Makassarl Pewawancara: Maria Ulfa, Universitas Muslim Indonesia (UMI), Makassar.

Widyaresti, E. P., \& Setiawan, A. H. (2012). Analisis Peran BRI Unit Ketandan dalam Pemberian Kredit Usaha Rakyat bagi Pengusaha Mikro dan Kecil di Kecamatan Ngawen Kabupaten Klaten. Diponegoro Journal of Economics, 1(1): 1-11. 